\title{
It's Hard, but I Can Do It: How an Independent Engineering Fair Project Can Affect Student Perceptions Of Science
}

\author{
Kelly Feille ${ }^{a,}$, Annie N. Wildes ${ }^{b}$
}

$\begin{array}{ll}\text { Received } & : \text { 10 May 2021 } \\ \text { Revised } & : \text { 23 August } 2021 \\ \text { Accepted } & : \text { 7 September } 2021 \\ \text { DOI } & : \text { 10.26822/iejee.2021.226 }\end{array}$

a: Corresponding Author: Kelly Feille,

University of Oklahoma in Norman, USA.

E-mail: feille@ou.edu

ORCID: https://orcid.org/0000-0002-5320-7641

bAnnie Wildes,

Choctaw, USA.

E-mail: anniewildes@yahoo.com

\begin{abstract}
Incorporating authentic engineering practices into educative experiences in elementary school has the potential to positively impact student consideration of STEM careers and increase student self-efficacy in later engineering study. Additionally, as students move from primary to secondary grades, their interest in STEM topics tends to decline. To that end, teachers and researchers at Chaparral Elementary facilitated an independent engineering fair project to engage students in authentic practices of engineering to solve a self-identified problem with a designed or improved solution. We investigated how students' perceptions of science and engineering were affected by their engagement in the practices of engineering through a two-week long independent engineering fair project. Data sources for the study include student surveys, researcher qualitative memos, informal student interviews, and student presentations. Our findings indicate that as students engaged with their independent engineering projects, their understanding of science as a tool for explaining the natural world improved and their perceptions of science and engineering and themselves as scientists and engineers was positively impacted.
\end{abstract}

\section{Keywords:}

Elementary Science, Elementary Engineering, Engineering Fair, Student Perceptions

\section{Introduction}

$\mathrm{T}$

he introduction of engineering practices in elementary school has the potential to positively impact student consideration of careers across science, technology, engineering, and mathematics (STEM) fields (National Academy of Engineering and National Research Council, 2009; Ritz \& Fan, 2015). Engineering design is an iterative process that introduces students to the notion that there are likely multiple solutions to a problem through a context requiring relevant content knowledge across STEM domains (National Research Council, 2009). In addition to supporting 21st century skills such as problem solving through a reflective, collaborative process using higher-order thinking 
(Fan \& Yu, 2017; Marulcu \& Barnett, 2015; Wendell et al., 2017), engineering processes have been shown to support student content understandings in science (Atman et al., 2007; Capobianco et al., 2015; English \& King, 2015; Guzey et al., 2017; Marulcu \& Barnett, 2015; Wendell \& Rogers, 2013).

As students move from elementary school to secondary school, their interest in science tends to decline (Christidou, 2011; Kang \& Keinonen, 2018; Potvin \& Hasni, 2014b). However, introducing engineering practices to students in the early grades has been shown to increase their self-efficacy in engineering in the college years (Fantz et al., 2011). To this end, additional research is needed to understand in what ways engineering can be implemented into elementary school curriculum and how it impacts students' perceptions of STEM practices and career fields (McCormick \& Hammer, 2016; McFadden \& Roehrig, 2019).

\section{Background}

Traditionally, elementary teachers have attempted to engage students in authentic science through the inclusion of science fair projects. Some argue that science fairs serve as a source of anxiety for teachers, parents, and students (Carrier, 2006) and that the common step-by-step formulaic processes do not connect students to authentic science (Magee \& Flessner, 2012). However, science-fair projects that promote student-guided inquiry have the potential to increase student self-efficacy in science (Dionne et al., 2012) and increase student attitudes towards and understanding of inquiry (Schmidt, 2014). Additionally, engaging in student-centered inquiry experiences in science can aid students as they approach more complex scientific concepts (Bellipanni \& Lilly, 1999).

Combining an approach towards elementary science education that values the inclusion of engineering processes and student-centered, autonomous, inquiry experiences we worked with three fifth-grade teachers at a local elementary school to design and implement an independent engineering fair. We used the engineering fair experience to investigate how students approach the process of engineering design and how completing an individual project impacted their perceptions of science.

\section{Science Project Fairs}

Science fairs have traditionally been used to engage students in authentic science and researchers have concluded that engaging students earlier with hands-on experiences in science eases the transition to complex scientific concepts (Bellipanni \& Lilly, 1999) Dionne and colleagues studied students' motivational factors for participating in science fairs and the influence on their interest in STEM careers. Factors included an interest in science, self-efficacy, assurance of achievement, social aspect, and working on strategies to gain scientific knowledge. The authors stated, "for teachers who strive to make science more appealing to a larger audience of students, science fairs are considered to be promising pedagogical activities because they promote inquiry-based learning" (Dionne et al., 2012, p. 672). Schmidt (2014) confirmed participation in science fairs increased students' attitudes and understanding of inquiry. The study revealed students who have more autonomy over their projects gained the most positive attitudes towards science (Schmidt, 2014).

\section{Engineering as a Tool to Learn Science}

The Nebraska Project was a collaboration of the College of Engineering and Technology and the College of Education and Human Sciences at the University of Nebraska-Lincoln and designed for middle and high school math and science teachers. The program focused on increasing teacher awareness of engineering and increasing their self-efficacy in teaching engineering. Teachers participating in the programs reported an increase student interest in math, science, and engineering. In the second year of the program, researchers specifically asked students if their interests towards STEM were increased. Eightysix percent of the students said they "strongly agreed" or "agreed" they learned something from their lessons and $75 \%$ stated the lessons increased their interest in STEM. The concluding impact on students also showed increased awareness and interest in engineering (Nugent et al., 2010). These findings suggest a positive influence on students' attitudes and interest in STEM.

Engineering poses real-world solutions to problems and students are given the autonomy to solve them (Cunningham \& Lachapelle, 2014). It is not surprising that studies show an increase in students' interest in STEM careers when engineering design is incorporated in curriculum (Benenson, 2001; Cunningham \& Lachapelle, 2014; Fortus et al., 2004; Silk et al., 2009). Engineering challenges situated in the real world are often attractive to and motivating for students, particularly those who are otherwise underserved or underrepresented in the discipline (Cunningham \& Lachapelle, 2014). Fortus and colleagues (2004) supported using design-based science (DBS) to increase student knowledge and interest in science. Current curriculum, they argued, is not based in real-world problems where students struggle through decisions that are not easy to make (Fortus et al., 2004). In addition to solving realworld problems of relevance to students, including engineering design in the classroom allows students 
to question their data when it is contrary to what they believe to be right (Benenson, 2001) and students can represent their ideas with concrete artifacts (Fortus et al., 2004).

Silk, Schunn, and Cary (2009) conducted a study of the pre-post gains of scientific reasoning of eighthgrade students located in a high-needs urban setting. The methods of instruction consisted of an emphasis on DBS, inquiry, and textbook curriculum supporting science methods used in the DBS project. Results concluded significant gains in science reasoning using all three methods of teaching, with DBS curriculum showing the most gains. The study concluded "student's knowledge of science reasoning improves if it is taught explicitly in a rich context" (Silk et al., 2009, p. 219).

Ganesh and Fulton (2011) also supported using engineering-design projects to increase students' knowledge in science and technology when they are involved in the learning process. Using engineering design over a two-year period, the authors wanted to determine the characteristics of a successful learning experience for middle school students. Characteristics included: hands-on experiences using engineering design, using the instructional sequence of the $5 \mathrm{E}^{\prime} \mathrm{s}$ (engage, explore, explain, elaborate, and evaluate), access to technology and tools, and an apprenticeship with university students and engineers. Students became empowered and gained knowledge in technology (Ganesh \& Fulton, 2011).

\section{Engineering and Student Self-Efficacy, Interest, and Attitude Towards STEM}

A study of college students determined those who were exposed to engineering practices at a younger age tended to be more interested and have higher self-efficacy in engineering (Fantz et al., 2011). Inspired by this research, Zhou and colleagues (2017) studied the influence of engineering at the middleschool level. Their study investigated how toy-design activities increased students' self-efficacy in and knowledge of engineering design. Students with limited experience in engineering design may have lower self-efficacy and thus not enroll in engineering programs later in their schooling career. Fostering selfefficacy as early as elementary could help increase interest in engineering. The study included 24 middle school students between the ages of 13-14 who were engaged in building relatable objects they could play with, such as a Marshmallow Challenge and Nerf Blaster Dissection, capitalizing on relevance and students' prior knowledge and skills. The results of the study showed an increase in self-efficacy in engineering as well as increased knowledge of engineering design (Zhou et al., 2017).

\section{Engineering in Elementary}

While there is little present research investigating how exposure to the processes of engineering design affects elementary students, researchers have suggested exposure to science and engineering as early as elementary school may have a positive effect on students' self-efficacy, attitude, and interest in science (Cunningham \& Lachapelle, 2014; Samuels \& Seymour, 2015; Zhou et al., 2017). The current literature is centered on middle and high school students, suggesting more research is needed at the elementary levels (Cunningham \& Lachapelle, 2014; Dionne et al., 2012; Hirsch et al., 2007; McFadden \& Roehrig, 2019; Nadelson et al., 2015).

\section{Student Perceptions of Science and their Possible Selves}

Student perceptions of their possible future selves are influenced by their current identity and experiences and represent specific, personalized conceptions of who one could become in a given social context (Markus \& Nurius, 1986). For students to imagine their future possible selves engaging in science coursework or careers, they need to feel as though there is a place for them in science and that they possess the competencies required. Engaging students in authentic, relevant, problem-driven science experiences has the potential to positively affect student perceptions of and motivation for science learning (Hellgren \& Lindberg, 2017; Kang \& Keinonen, 2018; Potvin \& Hasni, 2014a).

\section{Context}

This study was conducted at Chaparral Elementary (a pseudonym). Chaparral Elementary includes grades pre-k through fifth and is in a suburban setting in the central United States. Upon enrollment, a majority (55.8\%) of the 513 students were identified as Caucasian, $12.7 \%$ Hispanic, 7\% Black, 5.1\% Native American, $1.4 \%$ Asian, and $18.1 \%$ two or more races. Over half of the students (56.3\%) are eligible for Free/ Reduced Lunch. On state readiness testing, 47\% of all fifth-grade students scored proficient and above (Office of Educational Quality \& Accountability, 2017). Fifth-grade classes at Chaparral Elementary are 1:1, meaning for each student in the class there is a laptop computer available for use. In addition, at the time of the study the district utilized Google Classroom for student-teacher communication and assignments that require the use of technology.

The independent engineering fair took place over a two-week period near the end of the academic year, after state testing (see Feille et al., 2021a). Students were asked to identify a real-world problem they were interested in, research possible solutions, use research 


\section{iejee}

findings and content knowledge to design or improve a solution, communicate their proposed solution through the use of drawn prototypes, and present their process at the close of the fair. The design portion of the project focused students on an iterative process using drawn sketches for generation and communication of student ideas, an important step prior to constructing physical prototypes (McFadden \& Roehrig, 2019).

This qualitative, single case study investigates the effect of individual engineering fair projects as authentic science teaching and learning experiences. Participants in the larger study include fifth grade students across three classes and their classroom teachers. This manuscript includes only studentfocused data and investigates the question, how does participation in an individual engineering fair project affect student perceptions of science?

\section{Participants}

The participants in this study include 29 of 90 fifth grade students in three classes. Although all 90 fifth grade students completed the engineering fair projects, the students included in the study provided both parent permission and student assent to contribute data to the study. All identifying information was immediately removed from student data and each assenting student was assigned a unique numerical identifier and later a pseudonym. To avoid the identification of any participants, only the student's gender and assigned class remain as an identifying feature in the reporting of data (see Table 1).

Table 1

Consenting student participants

\begin{tabular}{lrr}
\hline Class & Male & Female \\
\hline Ms. Powers* & 5 & 5 \\
Ms. Myer* & 5 & 7 \\
Ms. Ferguson* & 2 & 5 \\
\hline
\end{tabular}

Note: Teacher names are pseudonyms

\section{Data}

The data sources used in this study include a student survey (Elementary Student Perceptions of Science Instrument [ESPOSi]), researchers' observations and field notes collected throughout student work and presentation of individual engineering fair projects, as well as recorded and transcribed informal interviews conducted at student presentations.

The ESPOSi student survey seeks to provide a baseline of student understandings of science as an explanation of the natural world, view and value of science, and view and value of formal science learning (Nettles et al., 2018). The survey utilizes multiple modes of questioning including single-choice and multiplechoice as well as open-response questions. Student responses are then coded as Low-Mid-High for each question utilizing a rubric (see Appendix). Finally, students are described as Low-Mid-High for each of the three focus areas (science as an explanation of the natural world, view and value of science, and view and value of formal science learning).

The research team moved among classes while students worked on their individual engineering fair projects and for student final presentations of their projects acting as participant observers. During this time, the research team interacted with students inviting them to describe their ideas and thoughts about the process. Detailed field notes and postexperience reflections were recorded to describe observations of student work, student-teacher/ student-student interactions, and any notable questions or descriptions.

Finally, consenting student presentations were audio recorded and prototype drawings and diagrams were photographed. At the close of their presentation, each student was asked if their ideas about science and engineering had changed throughout the project as well as how they now thought of themselves as scientists and engineers. Responses were audio recorded and hand transcribed.

\section{Method}

Prior to beginning their individual engineering fair projects, each student completed the ESPOSi online using Qualtrics (Qualtrics, 2018) and their assigned laptop computer. For nine school days, the students spent approximately one hour each day on their engineering fair projects. Table 2 outlines the timeline of the study.

\section{Table 2}

Study outline

\begin{tabular}{lll}
\hline Study Day & Event & Data Collected \\
\hline Prior to & Obtain parent permission & ESPOSi Survey Data \\
project & ESPOSi & \\
Day 1 & Topic Brainstorm & Observational Memos \\
Day 2 & Purpose & Observational Memos \\
Day 3 & Background Research & Observational Memos \\
Days 4 - 6 & Prototype Plan & Observational Memos \\
Days 7 - 8 & Improve Prototype Design & Observational Memos \\
Day 9 & Present project and final & Audio recorded Student \\
& prototype design. & Presentations \& Informal \\
& & Interviews \\
\hline
\end{tabular}

ESPOSi results were analyzed according to the survey rubric (See Appendix). Field notes and informal student interviews were transcribed and coded using MAXQDA 2018 (VERBI Software, 2017) for data analysis. Using constant comparative analysis (Glaser, 1965), data segments were coded primarily with themes 
taken from the ESPOSi student survey (science as explanation of natural world, view and value of science, and view and value of formal science learning) and secondarily with themes that emerged throughout data collection and analysis (Stake, 2010). Regular research team meetings were used to identify researcher agreement and discuss instances of conflicting coding to come to consensus.

Student silhouettes were then constructed using individual ESPOSi results paired with coded data segments from research memos and presentation transcriptions. Silhouettes of the participants lack the detail of portraiture (Lawrence-Lightfoot \& HoffmannDavis, 1997) but can provide an "outline or shadow" of the individual participant and their perceptions of science throughout the independent engineering fair project (Feille et al., 2018, p. 33).

\section{Findings}

Researcher memos and field notes were used to investigate student perceptions of science throughout their experience participating in an independent engineering fair. Informal student interviews and student presentation data provide a source of triangulation in conjunction with ESPOSi preexperience survey results.

\section{ESPOSi}

Fifth grade students at Chaparral Elementary generally demonstrated Mid-level perceptions of formal science learning $(N=25)$. This indicates that students generally associate science learning with passive learning practices related to specific content; and when learning is active students refer to general descriptions of practice such as "experiments" or "hands-on." Only three students demonstrated a Low perception of formal science learning while zero demonstrated a High perception of formal science learning. Students can be described as demonstrating Mid $(N=11)$ to High $(N=14)$ perceptions of science indicating that students see science as a meaningful enterprise, applicable to career choice, and necessary at the basic level of knowledge for society. In addition, students may initially turn to scientific practices as methods for problem solving. Very few students ( $N=$ 3) demonstrated a Low perception of science. Most student participants indicated Low $(N=20)$ to $\mathrm{Mid}$ $(N=8)$ conceptions of science as a way of knowing and understanding the natural world. This reveals that although they are aware of science as a field of study, the application of scientific practices and knowledge may be limited to an academic or content-specific setting. Table 3 describes the ESPOSi rubric coding by question.

\section{Field Observations}

Throughout student work on their independent engineering fair projects, researcher field memos revealed that although students frequently struggled with the autonomy of the project (Brophy et al., 2008), they appreciated attending to a topic they had interest in (Brown, 2017; Cunningham \& Lachapelle, 2014). Early in the project, a lack of knowing the nature of engineering practices resulted in student frustrations for a few students who shared an intense focus on finding the "right answer" (Memo_Day2). Due to the novelty of the engineering practices, many students also struggled to understand their role related to their self-identified problem (Memo_Day3). The novelty of the process and the lack of a "right" answer required scaffolding and prompting for some students more than others (Lou, 2015; McFadden \& Roehrig, 2019). Some of students' struggles seemed to relate to individual teacher's teaching engineering self-efficacy (see Feille et al., 2021b). As the teachers' confidence in facilitating the engineering fair project gained, so did students' comfort. Through teacher scaffolding and reassurance, students eventually came to understand that their purpose was to create or improve upon a solution to their identified problem and that failure along the way was all a part of the process (Memo_Day4).

Over the course of the project, students generally moved away from a more simplistic view of science as a way of knowing where they talked primarily of science topics from the context of an academic setting towards a broadened view of science and engineering in real-world contexts (English \& King, 2015). Because the project focused students' attention on identifying a problem and designing their selfconceived solution, students were free to capitalize on their own creativity rather than work within prescribed situations and scenarios (Memo_Day4). By the end of their experience, many students reflected upon the broader application of scientific and engineering practices for problem solving and understanding phenomena of the natural world (Fortus et al., 2004).

\section{Table 3}

ESPOSi Results by question

\begin{tabular}{llllllllll}
\hline & \multicolumn{1}{l}{ Perception of Formal Science Learning } & \multicolumn{2}{c}{ Perceptions of Science } & \multicolumn{3}{c}{ Science as a way of knowing } \\
\hline & Q1 & Q2 & Q3 & Q4 & Q1 & Q2 & Q3 & Q1 & Q2 \\
Low & 12 & 11 & 4 & 5 & 8 & 3 & 1 & 18 & 20 \\
Mid & 15 & 16 & 13 & 4 & 8 & 20 & 3 & 10 & 8 \\
High & 1 & 1 & 11 & 19 & 12 & 5 & 24 & 0 & 0 \\
\hline
\end{tabular}




\section{iejee $\approx$}

Additionally, several students were forced to recognize how their current scientific understandings could limit their proposed solutions but used the project to support scientific research and investigation on their own (Ganesh \& Fulton, 2011). Rather than seeing limited content knowledge as a dead end, students instead identified who might be important design partners or resources as their proposed prototype moved forward (Memo_Day5).

\section{Student Presentations}

"I thought like, science, and (pause) technology and stuff like that. I always thought it was circuitries, and circuit boards, and wires, and speakers and batteries. and all that stuff. But really it's like everything. Science is everything" (Lena_presentation). During student presentations, students continued to reflect upon how they think about science differently after the project, "I think science can be a lot more fun than I first thought about it" (Jeremy_presentation). Students talked about science as broader than how they originally conceptualized the subject, more than "just chemicals". "Science is pretty much anything that is man-made and like a helpful, like piece of material that helps us in the world" (Marc_presentation). They continued to describe science as difficult or hard, but their perceived self-efficacy was improved with several students indicating "science is hard, but I can do it" (Memo_presentations).

Embracing the value of failure was something several students mentioned in their presentations celebrating that repeated failure usually ends in success, "You might fail 1,000 times. As long as you make it once, it doesn't matter" (Eddie_presentation). The persistence they experienced contributed to their understanding of engineering, "Well, it doesn't always work the first time. You have to go through it multiple times. You have to brainstorm, one idea, your first idea isn't going to work. That's for sure. You have to keep it and add on to it" (Hannah_presentation). Problems in design frustrated some students and had them grappling with how much support or feedback they really wanted, "(I felt) frozen, like I wasn't really sure what to do...and sometimes getting too much help is baddish, then you also want to ask for help when you need it the most" (Elijah_presentation).

Students also described science and engineering as progress, tools to make the world a better place (Lena_ presentation). They recognized that their creativity played a role in using the tools and practices of science and engineering to improve their world, "I learned that really science could be anything. Like whether it's a rock or it's a new computer. And that really that, like, if you are creative, you can make an entirely new line of technology" (Jasmine_presentation). For some, being able to showcase their creativity contributed significantly to their enjoyment of the project, "I had a lot of fun doing this project...(be)cause I saw a lot of creativity in it. And I love doing creative things" (Ella_ presentation).

A very small number of consenting students ended up without completed projects. It is possible that a fear of failure contributed to student apathy (Memo_ presentations). One student admitted he usually quits on projects like this, but he committed to finishing this project and wished he had done more.

I know I could have had a better problem and a better answer just because I wanted to rush through it. I feel kind of happy about it because I actually did something...Usually I don't get finished with problems and work like this. I wish I could have done a better job (Roman_presentation, Memo_presentations).

The limitations of time and the constraints of the formal classroom environment hindered some students. "To do one project takes a long time" (Justin_presentation) and some struggled with the structure of the slideshow, so many students were not at the point they hoped to be by the time of the presentations.

\section{Silhouettes}

When considering science as an explanation of the natural world, students generally described science as broader than they originally thought. Science became for them a tool to understand more about their world through the independent engineering fair project. Students' views and values of science were impacted as they began to consider themselves as ones capable of doing science and engineering. They appreciated the creative aspect associated with solving authentic and relevant problems (Brown, 2017; Cunningham \& Lachapelle, 2014; Nugent et al., 2010). For several of the students, the experience shifted their views towards formal science learning as they began to see learning in the science classroom as something they could enjoy and desire to work hard for. A selection of student silhouettes is shared in Table 4.

\section{Concluding Statements}

Students entered the engineering design process with an emerging understanding of science as a tool to explain the natural world and did not consider the practices of science and engineering when approaching problems. Students may not have seen themselves as scientists or engineers prior to engaging in the independent engineering fair project and instead considered science primarily in the context of schoolwork rather than a personal endeavor. However, working through their self-identified problem to conceptualize a new or improved 
Table 4

Selected Participant Silhouettes

\begin{tabular}{|c|c|c|}
\hline Pseudonym & ESPOSi & Silhouette \\
\hline Elijah & $\begin{array}{l}\text { Low Perceptions of Formal Science } \\
\text { Learning } \\
\text { Low Perceptions of Science } \\
\text { Low Conceptions of Science as a } \\
\text { way of knowing }\end{array}$ & $\begin{array}{l}\text { Entering the project with overall low perceptions of science, } \\
\text { Elijah struggled with the patience to commit to solving his prob- } \\
\text { lem. He encountered several problems with his design that had } \\
\text { him feeling "frozen" and unsure with how much help to ask for. } \\
\text { Despite persisting through the project, he admitted he doesn't } \\
\text { see himself as an engineer because he doesn't have the "pa- } \\
\text { tience for things." }\end{array}$ \\
\hline Sadie & $\begin{array}{l}\text { Low Perceptions of Formal Science } \\
\text { Learning } \\
\text { Mid Perceptions of Science } \\
\text { Low Conceptions of Science as a } \\
\text { way of knowing }\end{array}$ & $\begin{array}{l}\text { Sadie entered the project with a low perception of formal sci- } \\
\text { ence and science as a way of knowing. She acknowledged that } \\
\text { the project helped her learn a lot about how things work and } \\
\text { thanks to the project she kind of "got into (science) now". The } \\
\text { project helped her value the processes of science and engineer- } \\
\text { ing, admitting that she can't just "do something random" and } \\
\text { expect it to work out. }\end{array}$ \\
\hline Jasmine & $\begin{array}{l}\text { Mid Perceptions of Formal Science } \\
\text { Learning } \\
\text { Mid Perceptions of Science } \\
\text { Low Conceptions of Science as a } \\
\text { way of knowing }\end{array}$ & $\begin{array}{l}\text { Jasmine began the engineering fair project with mid-level views } \\
\text { of science and a low conception of science as a way of know- } \\
\text { ing. But through the project learned that science is broader than } \\
\text { her previous conceptions. Coming to understand the role of } \\
\text { creativity helped her to engage with the project acknowledging } \\
\text { that her desire to be creative could contribute to her future as } \\
\text { an engineer. }\end{array}$ \\
\hline Roman & $\begin{array}{l}\text { Mid Perceptions of Formal Science } \\
\text { Learning } \\
\text { High Perceptions of Science } \\
\text { Low Conceptions of Science as a } \\
\text { way of knowing }\end{array}$ & $\begin{array}{l}\text { Roman started the project with a varied perception of science. } \\
\text { While he valued science and tolerated the formal classroom, } \\
\text { he had low conceptions of science as a way of knowing. He } \\
\text { described himself as a student who usually rushes through work. } \\
\text { Completing the project gave him a sense of pride, despite ad- } \\
\text { mitting he knew he could have done better. }\end{array}$ \\
\hline Addie & $\begin{array}{l}\text { High Perceptions of Formal Sci- } \\
\text { ence Learning } \\
\text { High Perceptions of Science } \\
\text { Mid Conceptions of Science as a } \\
\text { way of knowing }\end{array}$ & $\begin{array}{l}\text { Addie began her project with high perceptions of science. She } \\
\text { already understood the incredible reach of science knowing } \\
\text { that "we could do things that seem completely impossible - but } \\
\text { it happens and it is possible." Engineering was new to Addie and } \\
\text { understanding that it is more than "just building" but "constantly } \\
\text { improving upon other things" allowed her to see herself as an } \\
\text { engineer. }\end{array}$ \\
\hline
\end{tabular}

solution allowed many of them to see the practices of engineering as tools to use for problem solving and the scientific content related to their problem as a means to better understand and explain the world around them. Additionally, engaging in the project helped them understand the nature of engineering and the iterative process of prototype design and improvement resulting in a persistence through and appreciation for the process of failure.

This has significant implications to the field of science education and the endeavor to encourage students from all cultural backgrounds and genders to enter STEM fields, therefore addressing the issues of diversity within STEM careers (National Science Board, 2020). Students must first identify as one capable of doing science or engineering before considering a STEM career (Capobianco et al., 2015). Through the independent engineering fair project, each student worked as an engineer and scientific researcher as they sought to design or improve a solution to their identified problem allowing them to identify as capable of engaging in the practices of science and engineering.

The timing of authentic engagement with the practices of engineering during the fifth-grade year may address the decline in interest in STEM students experience as they move from elementary to secondary grades (National Academy of Engineering and National Research Council, 2009). If a task such as the independent engineering fair can address students' perceptions of science and formal science learning, it is possible that value of and commitment to STEM course work and endeavors can be positively impacted (Fantz et al., 2011).

This study is limited by scale, with a participant population including only one third of fifth grade students in a single school. Additionally, our participants were not hindered by traditional constraints related to district and state-mandated testing due to the timing of the project. This leaves room for future studies to consider the ways that this process might be integrated throughout the school year and warrants investigation into how the implications may change with a more inclusive, intentional, school-year long focus.

\section{References}

Atman, C. J., Adams, R. S., Cardella, M. E., Turns, J., Mosborg, S., \& Saleem, J. (2007). Engineering Design Processes: A Comparison of Students and Expert Practitioners. Journal of Engineering Education, 96(4), 359-379. https://doi. org/10.1002/j.2168-9830.2007.tb00945.x 


\section{iejee}

Bellipanni, L. J., \& Lilly, J. E. (1999). What Have Researchers Been Saying About Science Fairs? Science and Children, 36, 46-50.

Benenson, G. (2001). The unrealized potential of everyday technology as a context for learning. Journal of Research in Science Teaching: The Official Journal of the National Association for Research in Science Teaching, 38(7), 730-745. https://onlinelibrary.wiley.com/doi/pdf/10.1002/ tea.1029

Brophy, S., Klein, S., Portsmore, M., \& Rogers, C. (2008). Advancing engineering education in P-12 classrooms. Journal of Engineering Education, 97(3), 369-387. https://doi. org/10.1002/j.2168-9830.2008.tb00985.x

Brown, J. C. (2017). A metasynthesis of the complementarity of culturally responsive and inquiry-based science education in K-12 settings: Implications for advancing equitable science teaching and learning. Journal of Research in Science Teaching, 54(9), 1143-1173. https://doi.org/10.1002/tea.21401

Capobianco, B. M., Yu, J. H., \& French, B. F. (2015). Effects of Engineering Design-Based Science on Elementary School Science Students' Engineering Identity Development across Gender and Grade. Research in Science Education, 45(2), 275-292. https://doi. org/10.1007/s11165-014-9422-1

Carrier, S. J. (2006). The road to stress-free science fairs. Science and Children, 44(1), 36-39.

Christidou, V. (2011). Interest, attitudes and images related to science: Combining students' voices with the voices of school Science, teachers, and popular science. International Journal of Environmental \& Science Education, 6(22), 141159. https://files.eric.ed.gov/fulltext/EJ944846. pdf

Cunningham, C. M., \& Lachapelle, C. P. (2014). Designing engineering experiences to engage all students. Engineering in Pre-College Settings: Synthesizing Research, Policy, and Practices, 117-140. https://doi.org/10.2307/j.ctt6wq7bh.10

Dionne, L., Reis, G., Trudel, L., Guillet, G., Kleine, L., \& Hancianu, C. (2012). Students' sources of motivation for participating in science fairs: An exploratory study within the Canadawide science fair 2008. International Journal of Science and Mathematics Education, 10(3), 669-693. https://doi.org/10.1007/s10763-011-93188
English, L. D., \& King, D. T. (2015). STEM learning through engineering design: fourth-grade students' investigations in aerospace. International Journal of STEM Education, 2(1), 14. https://doi. org/10.1186/s40594-015-0027-7

Fan, S.-C., \& Yu, K.-C. (2017). How an integrative STEM curriculum can benefit students in engineering design practices. International Journal of Technology and Design Education, 27(1), 107129. https://doi.org/10.1007/s10798-015-9328-x

Fantz, T. D., Siller, T. J., \& Demiranda, M. A. (2011). Precollegiate factors influencing the self-efficacy of engineering students. Journal of Engineering Education, 100(3), 604-623. https://doi. org/10.1002/j.2168-9830.2011.tb00028.x

Feille, K., Nettles, J. R., \& Weinburgh, M. H. (2018). Silhouettes of Development: A Tool for Understanding the Needs and Growth of Science Teachers. Journal of Science Teacher Education, 29, 1-16. https://doi.org/10.1080/1046 $560 \times .2017 .1422644$

Feille, K., Pyle, J., Marshall, J., Wildes, A. (2021b) It's not a perfect thing: Facilitating an independent engineering fair with fifth grade students. Annual conference of the American Educational Research Association.

Feille, K., Wildes, A., Pyle, J., \& Marshall, J. (2021a). Inspiring young minds with an elementary engineering fair. Science and Children.

Fortus, D., Dershimer, R. C., Krajcik, J., Marx, R. W., \& Mamlok-Naaman, R. (2004). Design-based science and student learning. Journal of Research in Science Teaching, 41(10), 1081-1110. https://doi.org/10.1002/tea.20040

Ganesh, T. G., \& Fulton, I. A. (2011). Design-based research: A framework for designing novel teaching and learning experiences in middle school engineering education. ASEE/IEEE Frontiers in Education Conference.

Glaser, B. G. (1965). The Constant Comparative Method of Qualitative Analysis. Social Problems, 12(4), 436-445. https://doi.org/10.2307/798843

Guzey, S. S., Harwell, M., Moreno, M., Peralta, Y., \& Moore, T. J. (2017). The Impact of Design-Based STEM Integration Curricula on Student Achievement in Engineering, Science, and Mathematics. Journal of Science Education and Technology, 26(2), 207-222. https://doi.org/10.1007/s10956$016-9673-x$ 
Hellgren, J. M., \& Lindberg, S. (2017). Motivating students with authentic science experiences: changes in motivation for school science. Research in Science \& Technological Education, 35(4), 1-18. https://doi.org/10.1080/02635143.2017.1322572

Hirsch, L. S., Carpinelli, J. D., Kimmel, H., Rockland, R., \& Bloom, J. (2007). The Differential Effects of Pre-engineering Curricula on Middle School Students' Attitudes to and Knowledge of Engineering Careers. 2007 37th Annual Frontiers In Education Conference - Global Engineering: Knowledge Without Borders, Opportunities Without Passports, S2B-17-S2B-21. https://doi. org/10.1109/fie.2007.4417918

Kang, J., \& Keinonen, T. (2018). The Effect of StudentCentered Approaches on Students' Interest and Achievement in Science: Relevant TopicBased, Open and Guided Inquiry-Based, and Discussion-Based Approaches. Research in Science Education, 48(4), 865-885. https://doi. org/10.1007/s11165-016-9590-2

Lawrence-Lightfoot, S., \& Hoffmann-Davis, U. J. (1997). The art and science of portraiture. Jossey-Bass. le.

Lou, Y. (2015). Design Fixation and Cooperative Learning in Elementary Engineering Design Project: A Case Study. International Electronic Journal of Elementary Education, 8(1), 133-146.

Magee, P. A., \& Flessner, R. (2012). Collaborating to improve inquiry-based teaching in elementary science and mathematics methods courses. Science Education International, 23(4), 353-365. http://eric.ed.gov/?id=EJ1001629

Markus, H., \& Nurius, P. (1986). Possible Selves. American Psychologist, 41(9), 954-969. https://doi. org/10.1037/0003-066x.41.9.954

Marulcu, I., \& Barnett, M. (2015). Impact of an engineering design-based curriculum compared to an inquiry-based curriculum on fifth graders' content learning of simple machines. Research in Science \& Technological Education, 34(1), 85-104. https://doi.org/10.1080/02635143.2015.10 77327

McCormick, M. E., \& Hammer, D. (2016). Stable Beginnings in Engineering Design. Journal of Pre-College Engineering Education Research (J-PEER), 6(1). https://doi.org/10.7771/21579288.1123
McFadden, J., \& Roehrig, G. (2019). Engineering design in the elementary science classroom: supporting student discourse during an engineering design challenge. International Journal of Technology and Design Education, 29. https:// doi.org/10.1007/s10798-018-9444-5

Nadelson, L. S., Pfiester, J., Callahan, J., \& Pyke, P. (2015). Who is doing the engineering, the student or the teacher? The development and use of a rubric to categorize level of design for the elementary classroom. Journal of Technology Education. https://doi.org/10.21061/jte.v26i2.a.2

National Academy of Engineering and National Research Council. (2009). Engineering in K-12 Education. National Academies Press. https:// doi.org/10.17226/12635

National Research Council. (2009). Engineering in K-12 education: Understanding the status and improving the prospects. National Academies Press.

National Science Board. (2020). The State of U.S. Science \& Engineering. https://ncses.nsf.gov/ indicators/

Nettles, J., Feille, K., \& Stewart, M. (2018). Informal summer science workshops and student perceptions of science. Presented at the Meeting of School Science \& Mathematics.

Nugent, G., Kunz, G., Rilett, L., \& Jones, E. (2010). Extending engineering education to K-12. Technology and Engineering Teacher, 69(7), 14-14.

Office of Educational Quality \& Accountability. (2017). Oklahoma School Profiles. http://oeqa.ok.gov/

Potvin, P., \& Hasni, A. (2014a). Analysis of the Decline in Interest Towards School Science and Technology from Grades 5 Through 11. Journal of Science Education and Technology, 23(6), 784-802. https://doi.org/10.1007/s10956-0149512-x

Potvin, P., \& Hasni, A. (2014b). Interest, motivation and attitude towards science and technology at K-12 levels: a systematic review of 12 years of educational research. Studies in Science Education, 50, 85-129. https://doi.org/10.1080/03 057267.2014.881626

Qualtrics. (2018). Qualtrics. http://www.qualtrics.com 
Ritz, J. M., \& Fan, S.-C. (2015). STEM and technology education: international state-of-the-art. International Journal of Technology and Design Education, 25(4), 429-451. https://doi. org/10.1007/s10798-014-9290-z

Samuels, K., \& Seymour, R. (2015). The middle school curriculum: Engineering anyone? Technology and Engineering Teacher, 74(6), 8-8.

Schmidt, K. M. (2014). Science fairs and science olympiad: Influence on student science inquiry learning and attitudes toward stem careers and coursework.

Silk, E. M., Schunn, C. D., \& Cary, M. S. (2009). The Impact of an Engineering Design Curriculum on Science Reasoning in an Urban Setting. Journal of Science Education and Technology, 18(3), 209-223. https://doi.org/10.1007/s10956-0099144-8

Stake, R. E. (2010). Qualitative research: Studying how things work. Guilford Press.

VERBI Software. (2017). MAXQDA 2018 [computer software]. VERBI Software. https://www. maxqda.com

Wendell, K. B., \& Rogers, C. (2013). Engineering DesignBased Science, Science Content Performance, and Science Attitudes in Elementary School. Journal of Engineering Education, 102(4), 513540. https://doi.org/10.1002/jee.20026

Wendell, K. B., Wright, C. G., \& Paugh, P. (2017). Reflective Decision-Making in Elementary Students\&apos; Engineering Design. Journal of Engineering Education, 106(3), 356-397. https:// doi.org/10.1002/jee.20173

Zhou, N., Pereira, N. L., George, T. T., Alperovich, J., Booth, J., Chandrasegaran, S., Tew, J. D., Kulkarni, D. M., \& Ramani, K. (2017). The Influence of Toy Design Activities on Middle School Students' Understanding of the Engineering Design Processes. Journal of Science Education and Technology, 26(5), 481-493. https://doi. org/10.1007/s10956-017-9693-1 


\section{Appendix}

Primary Code

\section{Science as a way of} knowing

Science is both a body of knowledge and the

processes and practices used to add to that body of knowledge.

Science knowledge is cumulative and many people,

from many generations and nations, have contributed

to science knowledge.

Science is a way of

people, not

just scientists. (Appendix HNGSS) knowing used by many

\section{Relevant ESPOSi Questions Low} would you think they were

Perceptions of Science. What are students understandings and perceptions of and ap preciation for science (as a tool, as a way of knowing, and as a potential career)?

Perceptions of forma science learning What are students understandings and perceptions of and appreciation for classroom-based science learning?

What do you hope your sci
What are some things that you know, if you are really good, or an expert at science?

If someone told you they were "doing science", what doing?

Click on each picture that you think of as Science.

If science was not a required subject to study (meaning people did not have to take science classes), how would it impact you? Your friends? Your

LOW: One-word response that is in nature

LOW: General response that is not specific to scientific explanation of the natural world

city? Your country?

Click in the box next to each career (job) that you think needs science

You notice that your birdfeeder in your back yard is running out of birdseed faster than usual. What would you do to find out why?

Click next to all of the things you expect to do in your next science class at school.

Which picture best shows what you think of when you think of science at school? ence class next year will be like? What do you hope will happen in science class?

Imagine you are at school and your next class is science. What will you be doing? ence processes or simplistic or genera

\section{Secondary Code}

Medium

High

MID: Provides simplistic evidence of understanding of the practices of science but is limited to a single facet of science as an explanation of the natural world

MID: General reponse that is related $\mathrm{HIGH}$ : Detailed response is to a scientific process related to a scientific proproviding explana- cess providing explanation ion of the natural of the natural world world

4-6

$7+$
LOW: Response that indicates a positive impact

Notes from text book or website

MID: General response that shows limited value of sci ence

$5-8$

Ask an adult who might know OR

ake down birdfeeder internet

Teacher demonstration

MID: Passive recipient of scientific knowledge or active participant without specific reference to scientific process or content

MID: Passive recipient of scientific

LOW: Vague response without reference to scicontent participant without pecific reference to scientific process or
HIGH: Detailed response that demonstrates an explicit understanding of science as a process to explain the natural world
HIGH: Specific response that details impact and personal and/or broader value of science

$9+$

Collect data and observations and investigate
Formal lab science

Learning about schoolyard habitat

OR

Lab with safety equipment

HIGH: Active participant in specific scientific processes or content content specific scientific processes or content
HIGH: Active participant in 